Received: 11.02.2014.

Reviewed paper

UDK: [371.3.012:81'243]-053.4

\title{
LEARNING OF FOREIGN LANGUAGE IN PRE-SCHOOL CHILDREN: EVALUATION METHODS IN KINDERGARTEN'S ENVIRONMENT
}

\author{
Maja Adžija, mag. \\ Filozofski fakultet Sveučilišta u Zagrebu \\ Ivana Lučića 3, Zagreb \\ E-mail:maja.adzija@gmail.com \\ Dr.sc. Joško Sindik \\ Institut za antropologiju, \\ Ljudevita Gaja 32, Zagreb \\ E-mail: josko.sindik@inantro.hr
}

\begin{abstract}
In this paper we describe how children acquire foreign language. It is well known that the very early age is a most suitable time to start foreign language learning. This is partly because up to the certain age every child learns foreign language as a part of a natural process. For our research we had to study theories of language learning, predominantly nativists' theory, where Chomsky argues that there is an innate factor, known as Language Acquisition Device, and further development made by Lennenberg, but also empiricists - behaviourists' theory upholding the element of imitating (Skinner) and cognitivists' theory that argues that cognition precedes the language development (Bruner, Piaget, Vygotsky, Sapir-Whorf). We are giving an overview of the process and ways of acquiring foreign language we studied the phases of language learning and connections to the brain's developmental stages. It is established that the most suitable age for starting the learning process should begin at preschool age, when children are mostly intrinsically motivated. For the evaluation of the process we suggested the simple quantitative and qualitative method, suitable for educators and parents and for the scientific purposes there is a micro genetic research method for deeper understanding of the learning process and changes that occur.
\end{abstract}


Key words: foreign language learning, intrinsic motivation, micro genetic research, quantitative and qualitative method

\section{INTRODUCTION}

The answer to the question "How do children learn foreign language?" can be found by observing how children learn language in general, during ontogenesis. Probably there are language universalities predetermined in child's predisposition or ability to acquire language (Marcos, 2009). It seems that children have great capacity for „statistically" language learning. However, we still do not have answers on: how children integrate all the information needed for language learning, how they choose rules applicable in specific situation, which signs are the best indicators of boundaries between words for children (Marcos, 2009).

\section{Basis of children language learning}

Children's exceptional ability of discriminating speech sounds are the basis for mother tongue learning, and with analogy foreign language learning. The first ability of discrimination of speech sound is common to all children, no matter their mother tongue, the level of complexity and its outspread (Doupe \& Kuhl, 1999). There are three theories of language learning:

1. nativists: child is learning a language by listening and detecting the formal categories (grammar) that are part of his innate knowledge (Chomsky, 1968, 1980; Lennenberg, 1967) Chomsky (1968) argues that we are born with innate Language Acquisition Device, which is a mental program for how to deal with language, but Lennenberg (1967) states that there is a deadline for acquiring language, i.e. "critical period" in child's life, that occurs the time reaching puberty.

2. Empiricists-behaviorists: child is learning language/speech by using it in communicational situation, by imitating adults and other children (Skinner, 1957, 1989). Skinner (1957) believed in the nurture theory. He believed that we can explain language development with familiar learning principles, such as association, imitation, and reinforcement.

3. cognitivists: in the field of cognitive abilities, cognition precedes the language development, while - this is a combination of nativist and empiricist (Jerome Bruner, Jean Piaget, Lev Vygotsky, Sapir-Whorf). Piaget (1967) first developed developmental stage theory which deals with the nature of knowledge itself and how humans come gradually to acquire, construct and use it. Vygotsky (1986), the founder of cultural - historical psychology claims that there is an inter-relationship of language development and thought and that it establishes the explicit and profound connection between speech (silent inner speech and oral language) and development of mental concepts and cognitive awareness. Bruner (1966) proposed, in his research of the development of children three modes of representation: enactive representation (action - based), iconic representation 
(image-based) and symbolic representation (language - based). He rejects the nativist theory of language acquisition and upholds a social interactionist theory of language development and proposes that social interactions play a fundamental role in the development of cognition in general and language in particular (Bruner, 1983). Sapir - Whorf (Sapir, 1921; Whorf, 1956) hypothesis can be described as consisting of two associated principles. According to the first, linguistic determinism our thinking is determined by language. According to the second linguistic relativity, people who speak different language perceive and think about the world differently. The structure of a language affects the ways in which its speakers conceptualize their world, i.e. their world view, or otherwise influences their cognitive processes.

There are two basic approaches that dominate all theories of language learning: the process of learning and in that way they acquire the language rules (1); the learning is less significant factor, comparing with the main role that have innate factors (Chomsky, 1968). Researches have shown that the representation of learning as a key factor is not coordinate with the main observation regarding language. Namely, language systems of the world are very similar and it is to presume that there are predetermined language universalities in child's predisposition or ability to learn language (Marcos, 2009).

The theoretic and research questions that interested the theoreticians of the language development are: How we acquire language learning? How children learn grammar? It is shown that in the "poor acquisition" conditions child has significant grammar knowledge (argument for innate factor). In the ways of isolating the grammar structures, the important role has experience of language acquisition (learning) (Skinner, 1958).

Connectionists approach is widely use in cognitive and neurological sciences, and it is based on the so called connectionists networks which explain phenomena of behavior in terms of nods („,whorls"), whose number gradually increases (French, 2008). The neurons networks "learn“ on the ground of exposing to the samples of stimulation (in this case, listening to the speech of the others): gradual changes are visible in the connections between units that form part of the model of the activation network (motoric and cognitive learning work the similar way). Afterwards comes to greater understanding and production. Neural networks offer possibility of getting a structural regularity even from relatively unclear input data. As soon as the network finds a solution for the tasks she is "learning" to perform, the representation of the language and other phenomena are being made (that is alternative explanation of generalization). "Network “ practices through exposing to great number of sample (speech), and units within the network can coordinate a large number of probabilistic limitations (especially „grammatical situation") (Clark \& Clark, 1977).

The crucial segment in second language acquisition is a second language use strategies. It is of great importance that the learners select these strategies to improve the learning of a second language. These language use strategies include retrieval strategies, rehearsal strategies, cover strategies and communication strategies. The strategies as a primary goal have language learning. For the awareness raising in using language learning strategies the role of consciousness is important as Schmidt (1994) stressed out that language learning strategies are „either within focal attention of the learners or within 
their peripheral attention", and it is possible that the learners identify what they have just done. If his behavior is unconscious and the learner is no table to identify strategies, than the behavior is a process, not a strategy.

As some researchers underscore learning strategies are to be seen in the context of general personality factors such as the following: introversion/extroversion, reflectiveness/impulsiveness, field independence/dependence, self-confidence, self-concept, self-efficacy, creativity, anxiety, and motivation (intrinsic/extrinsic) (Oxford \& Cohen 1992).

\section{Phases of language learning}

Children learn language through three phases: learning rhythmic characteristics of the language (1), segmentation of the words from fluent speech (2), identification of the exact grammar structure (3). There are three general rhythmic classifications of the languages: languages of the stressed syllables (English, German), rhythmic languages (French, Spanish), and languages of short syllables (Japanese). Research (Nazzi et al., 2000) has shown that children up to 5th month of life differentiate languages which belong to the different rhythmic categories (for ex. English and Japanese), but do not differ languages which belong to the same rhythmic categories (English and Dutch). Research conducted by Jusczyk \& Aslin (1995) has shown that children at the age of about 7,5 month begin to differ words within a fluent speech. Learning is essential for correct segmentation, although younger children manage to separate words within a fluent speech, it does not mean that they understand the meanings of these words. From the 15th to the 24th month of life the capacity to separate individual words within a context of fluent speech increases considerably. At the age of 15th - 24th month they achieve level of adults for recognizing familiar words in fluent speech. How children identify integral parts within a grammatical organization of the language? Identification of integral parts needs to satisfy several conditions, in which children are sensible: speech must contain an adequate sign to suggest integral parts of grammatical structure of the language: the listener must be able to detect those signs: the listener must use those signs in the process of input of the linguistic information.

The conclusion of these researches is as follows. The results show that children have great capacity of learning language "statistically". However, this area is still not explored enough, such as questions: How children integrate all the information needed for language learning? How they choose rules, applicable in a particular situation? Which signs are better indicators to mark boundaries between words?

Jeannette Vos (2008) conducted research about early foreign language learning capacities at preschool children. Her main thesis were: language learning is a natural process at younger age of the child (at the age of four, child knows 2000 words, while the 6 month old baby produces and differentiates 70 different sounds) (A): preschool age is vital for language learning (B); in first three years we form the foundations for thinking, language, vision, attitudes and aptitudes (C). This does not mean, however, that 50 to 80 percent of our wisdom is created in the early childhood. It simply means that children 
form, in the first few years of life, their main learning pathways in brain. So, we can teach a second language to young children using few methods. It can be done by imitating, observing, listening and performing, by counting, plays, rhymes and songs. It is very important to have fun: for emotional (reptile) brain or "little brain", when it turn on, the learning becomes much easier (Vos, 2008). Gardner's theory of multiple intelligences is applicable in the foreign languages method: learning by doing, emphasized with images and sounds; learning must be fun, in relax but stimulating state with music and rhythm, connecting numbers and words in play, roaching, tasting, smelling, and using the whole world as a classroom (Vos, 2008). The learning should be in a stimulating, enriched environment. By an enriched environment we mean the one that offers plenty of sensory stimulation. A brain researcher at the University of California at Berkley made an experiment with rats, producing, as a result, some of the world's most intelligent rats. When she put the rats in an enriched environment, i.e. their cages filled with mind intriguing games, stimulating colors, mirrors etc. After a while they grew more brain tissue. The rats in a non - enriched environment, as a result had less brain tissue (Diamond, 1988)

The context is important for foreign language learning in the pre-school age children (project Socrates, program of the EU). So, this process of learning has the elements: research - context, learning outcomes, direct observations of the situations in the classroom/group; parents involving - important when introducing foreign language learning, atmosphere of the support outside of the classroom (outside of the kindergarten); continuity - maintain continuity of the learning, from the preschool age throughout the education period; time - time of learning needs to be expanded, whenever it is possible; it is better to have shorter lessons everyday then two long ones during the week; it is also important the quality of the lessons; training of the educators - the knowledge of the foreign language, to know how to analyze and interpret language, the knowledge of the principles of the foreign languages learning, pedagogical capacities for foreign languages; possibilities for all students/children; suitable methodology for all age groups; language diversity; coordination of the research (covering all the important aspects); potential dangers - available resource, planning (Vos, 2008).

Brumen (2011) researched the perceptions of pre-school age children concerning foreign language learning motivation in pre-school age children (Slovenia). She confirmed that children are intrinsically motivated in foreign language learning; they are satisfied with their accomplishments, they seek activities, and they are eager to acquire knowledge. An atmosphere of support is important to them, as well as a stimulating environment and a feeling of security and comfort. (When these elements are lacking children want to learn less).

Because children are intrinsically motivated it is opportune to use their motivation and introduce foreign language through listening, seeing, imitating and practicing (Jensen, 1994; Dryden \& Vos, 1997; Dryden \& Rose, 1995). It is advised to introduce a second language as if it was a mother tongue, using songs, games, nursery rhymes and natural conversation with the children.

Without the element of fun, learning is almost impossible. Learning is easier if it is made fun or emotional, because, the brain stem, sometimes called the reptile brain, 
controls many of our body's involuntary functions, e.g. breathing. Besides the reptile brain, we have the emotional brain, the "little brain" and the thinking brain (Jensen, 1994; Dryden\&Vos, 1997; MacLean, 1990). The emotional brain or the mammalian is located in the center of the brain and stores memory (Jansen, 1994; MacLean, 1990; Dryden \& Vos, 1997), and that is why the learning is much easier if the emotional or fun element is involved. Other than that it is important to always keep our brain busy and to use it as much as possible in order to stay healthy. Neurons die if not used and the "little brain" is the only part where neurons grow (Jensen, 1994; Dryden \& Vos, 1998). In our brain there is several intelligence centers in which learning take place. The intelligence centers are stored within the cortex, or thinking brain. According to Gardner we have several types of intelligence: linguistic, logical - mathematical, visual - spatial, social, introspective, musical, bodily - kinesthetic and naturalistic (Gardner, 1983: 1998)

To link all those kinds of intelligences we can use several learning methods, e.g. learning by doing. Play cooking, going to grocery store or similar and using second or third language while doing it (Dryden \& Rose, 1995). The learning process should be reinforced with pictures and sounds in a playful way, using cards (Dryden \& Vos, 1997). As previously written, learning should always be fun, and learning while playing creates emotional attachments and emotions are the door to learning (Jensen, 1994: Dryden \& Vos, 1997). Learning should be stress: free, as the latest research shows, 80 percent of learning problems are stress related (Stokes \& Whiteside, 1984). It is known that the music for example is one way to use the whole brain, and there for easy to remember lyrics with music (Lozanov, 1978; Brewer \& Campbell, 1998). Although the traditional way to learn is to sit and learn it is easier to learn as we move. In that way we can learn more (Gardner, 1983; Dryden \& Vos, 1997). Students should be encouraged to talk to each other and practice what is learnt (Gardner, 1983; Dryden \& Vos, 1997), but before that the teachers should let children reflect for a while, because there is a dormant stage to language learning, and children tend to first absorb language and then speak (Krashen, 1992). It is important to bear in mind that anything can be linked while learning language, including for example numbers and new vocabulary words (Dryden \& Vos, 1997). To reinforce the memory, when learning new word we can include all senses, e.g. taste, smell (Dryden \& Rose, 1995). It is important to make a learning process as natural as possible and therefore we can use outdoors as a classroom (Dryden \& Vos, 1997).

\section{SECOND LANGUAGE LEARNING AND TEACHING AT PRE-SCHOOL CHILDREN}

Firstly we will stress the importance of early language learning, regarding to the age of the children. Every healthy child is born with 100 billion brain cells, and each cell makes up to 20000 connections. Whether these brain cells make connections or whether they die depends on if a child lives in an enriched environment (Buzan, 1984; Diamond, 1988 ; Ornstein, 1984, 1986). The ability young children have is to acquire knowledge as a part of a natural process. When they are immersed in a language, they can learn quickly 
and easily if playing. Unlike adults, who at some point in life lose that ability, they can learn verbs by hard, but speak naturally is much more difficult. So the key to fast and efficient language learning is to become more like children. Children learn, by the time they are four at least 2000 words, if exposed, in well-rounded environment. After the birth, in the first month baby reacts to the environment and develops new synaptic connections at the rate of up to three billion a second. All the baby's experiences are deposited in the memory cells. In the first six month of baby's life there are 70 sounds that each baby can produce, and those sounds make up all the languages of the world. After that period baby will use only the sounds from her/his direct environment and disregard the others. Up to the eighth month a baby's brain has about 1,000 trillion connections (Kotulak, 1996).

The child's vital years for natural learning are those in preschool period. In that period there is no difference between learning first or second language. By the third year of life the foundations for thinking, language, vision, attitudes, aptitudes and other characteristics are defined (Kotulak, 1996). During the first years of life children form their main learning pathways in the brain (Bloom, 1964). There are six main pathways to the brain and they include learning by sight, sound, taste, touch, smell and doing (Dryden \& Vos, 1997), after that period all the information we use are collected in that early stage of development. Up to age ten half of the connections have died in the average child. Five hundred trillion will last throughout an individual's lifetime. Foreign language teaching should begin when children are in preschool, when teachers can maximize a child's willingness and ability to learn. Up to age 12 the brain is like super - sponge, and during that period the foundations for thinking, language, vision, attitudes, aptitudes and other characteristics are laid down. After that period all the fundamental architecture of the brain is finished (Kotulak, 1996). It is important to learn a foreign language before that age, because, by the time a student reaches high school, the optimum learning period is lost. So, the methods of evaluation of the second language learning effects are the necessity.

\section{METHODS OF EVALUATION OF THE SECOND LANGUAGE LEARNING EFFECTS}

In pre-school education is of primary interest to encourage a child's optimal mental and physical development and it is important to know as objectively as possible to evaluate the current development status of the child, i.e. mental and physical characteristics of the child. Therefore, one should bear in mind three points:

1. children's developmental characteristics are the starting point and the final goal, the beginning and the end of each reflection of educational work with children: namely, developmental characteristics should be changed in the desired direction;

2. general principles of development: no matter how certain characteristics developed in specific children, it is always advisable to further stimulate its development;

3. principle of development holism: there is always a priority to encourage more intense those properties that are underdeveloped compared to the approximate "age ability of the children" (Sindik, 2008). 


\section{Simple quantitative method}

An evaluation of the development in the competences in mental and physical aspects of child development (motor skills, and maintain health, socio-emotional development and personality development, communication skills, creating and expression, cognitive abilities and knowledge) is very useful for the purposes of the prevention of special needs (Sindik, 2001, 2002a, 2002b). For this purpose, simple quantitative method was developed. The reasons for making such a method are the following: evaluating the characteristics can (and sometimes must) conduct a teacher who does not need to be particularly scientifically educated (and method of evaluation should be usable and simple); in practice often there are no possibilities to implement psychological testing (temporal or material).

The basic idea of the method is "logical" assumption that it is necessary to encourage intensively development of those mental and physical competences, that aren't at some point enough developed, and exactly in the degree in which they are "less developed", in relation to a defined desired final state. A simple quantitative method, predicts more state evaluation of selected characteristics (e.g., quarterly).

Evaluating the developmental status of the child can be implemented in two ways: the progress of children in relation to the initial state for each individual (how much the child has progressed in relation to the initial evaluation in a developmental area), or may be evaluate an absolute status or condition of the specific characteristics, regardless of initial state (when compared with the average of the group). The criteria for monitoring of the competence in each aspect of development can be differentiated on the binary evaluation of having or not having certain competences, i.e. the existence or lack of progress in relation to the initial state for each child (0) or to evaluation of the extent of progress and development of specific competencies (1). More sophisticated approach means using ordinal scale of estimations. Degrees of progress can be expressed as follows: $0=$ failure to progress, not having the trait, $1=$ less progress, having the trait to a lesser extent, 2 = average degree of having the trait or average progress, etc. (Sindik, 2001).

The sum of the data of the assessment is carried out at two levels (see Table 1):

- assessment by rows: represents the sum of the individual scores for all estimated characteristics (competences). Added together, the data (estimations) for a particular individual upon completion of the assessment obtained data on each child, indicate the "development status" of the child. When the sum of unsatisfactory developed competencies for each child in the group was calculated, the children could be ordered in relation to the total score (sum) in all the competences together. In other words, one can determine the overall status of certain child in the group, in relation to his/her all estimated characteristics together. The percentiles according to this sum can be used in defining, for example, $25 \%$ of children with results in the range from 75th to 100th percentile (individuals with the highest values of aggregate score), classified as "most developed" individuals (the best vocabulary learners, e.g.). On the other hand, $25 \%$ of individuals with lowest scores (with the sum with the results from zero to 25th percentile) can be classified as "least developed" (the worst vocabulary 
learners). The remaining $50 \%$ of children will probably be considered as "average" (vocabulary learners). Based on the classification of children in three (or more) of notional groups (based on the size of aggregate score, such as described percentile criterion), it will be easier to plan individual work with each child (for example, with children with special needs). This is in fact mathematically defined prevention at the individual level (Sindik, 2001).

- assessment by columns: represents the sum of the scores for the entire group (e.g., in certain educational groups of children in kindergarten), for each competence at all children together (for example, specific words in vocabulary). The sum of the columns is performed by summing the estimations in certain competences (in consecutive columns). In the last column, in the last row down right, the scores for all the children in all the individual characteristics are summed (sum for all the competences for entire group: sum for all the columns together). Higher percentage of the sum of the estimations by individual competences, in relation to the total sum of the estimations in all the characteristics, means higher developmental status in some competences in a given group. Namely, the sum of the estimations for the individual characteristics of the group is divided with the total sum of the estimations for all the participants (children in observed group), and the obtained quotient is multiplied by $100(\%)$. The priority list of competences which have to be stimulated in the future (for entire group of children) is defined. Stimulation should be done through various forms of planning and programming for the promotion of mental and physical development of certain group of children. By ranking of individual competences according to the calculated percentage, it is planned to more intensively encourage and stimulate the least developed competencies (for the whole group). After making such the list of priorities, practical educational work should be planned in a given group of children for the next time period. This is therefore mathematically defined stimulation priorities in vocabulary learning, adjusted to a current state in certain group of children in general (Sindik, 2001).

This simple quantitative method is applicable in virtually all areas of applied psychology, primarily due to the ease of data collection, aggregation of results and implementation of the planning and programming of future work, with the aim of achieving the desired final state. Furthermore, evaluation of the effects described above is possible to be automatized in its practical application, using the computer technology, facilitating its application, particularly in the domain of data analysis. It is important to take into account the selection of the optimal number of competences for evaluating the effects of the program (e.g. vocabulary): large a number of competences that are being monitored can increase the reliability and validity of the data, but it is problematic in terms of applicability in practice (more estimated competences request more time) (Sindik, 2008). 
Table 1 Example of the assessment of competences in children in a small group $(0=$ not competent, unsatisfactory situation; 1 = satisfactory condition for each competence)

\begin{tabular}{|l|l|l|l|l|l|l|l|l|l|}
\hline Child/Competence & 1 & 2 & 3 & 4 & 5 & 6 & 7 & 8 & $\begin{array}{l}\text { E Overall competences } \\
\text { - individual profile }\end{array}$ \\
\hline A. A. & 1 & 1 & 1 & 1 & 0 & 0 & 0 & 1 & 5 \\
\hline B. B. & 1 & 0 & 0 & 0 & 1 & 1 & 0 & 0 & 3 \\
\hline C. C. & 1 & 1 & 0 & 0 & 0 & 1 & 1 & 1 & 5 \\
\hline Profile - group $\Sigma$ & 3 & 2 & 1 & 1 & 1 & 2 & 1 & 2 & 13 \\
\hline $\begin{array}{l}\text { Engagement needed to im- } \\
\text { prove the competence (e.g. } \\
1 \ldots 8 \text { (specific vocabulary)) }\end{array}$ & 23 & 15 & 8 & 8 & 8 & 16 & 7 & 15 & $100 \%$ \\
\hline
\end{tabular}

In the example in Table 1 is showed that the hardest work in the future is needed for the competence No. 1 (column 1) where the sum of unsatisfactory developed competencies is greatest (3). So, $23 \%$ of the activities with children in an educational group in the kindergarten should be planned for a desirable change in this competence. At the competencies No 3, 4, 5 and 7, it is necessary to work only $8 \%$, because only one child did not reach a satisfactory level of competence: in these cases, individual work with certain children should be planned. In relation to prevention at the individual level, it is more likely that children AA and CC have more particular needs (the sum in the rows of five unsatisfactory developed competencies). For them, it has to be considered whether it is necessary for them to take further measures for some intervention or not (Sindik, 2008). The number of monitoring phases in this kind of "researches" of the child's development may include a minimum of two (starting point: at the beginning of school year and end: the end of school year), three (starting, intermediate and final); a larger number of phases (Sindik, 2008).

In practice, during early foreign language learning acquisition in kindergartens it is useful to examine how the learning of new foreign language learning reflects on:

- overall psychological and physical development (motor skills, cognition, socio-emotional development, communication);

- development of the speech (only speech aspect of the development, for. ex. vocabulary, pronunciation);

- direct cognition from the area of concrete foreign language (vocabulary, grammar etc.);

- child's choice among the activities he/she like, plays (for example, like to watch cartoons with foreign language);

- environmental conditions needed for the activities with the children (materials and organizational, context);

- participation of the children in selected and conducted activities by teacher (participation of some children during some activities, level of child's activity during certain 
activity).

For that purpose, data can be collected, estimations can be given, and observations can be done from: parents, educators, directly from children, expert assistants, external experts (Sindik, 2002a, Sindik, 2002b). Examining the effects and starting points of the program concepts of foreign language learning has shown that the starting points of the program are greatly compatible with desired effects: children acquire basic cognition on foreign language, learning through play (A); the consequence is the satisfaction of the parents (B). The same data about that are received from the different sources: children, parents, educators and other experts. The program of early foreign language learning is the frequent reason why children enroll certain kindergarten (Barać \& Sindik, 1999).

\section{Method of microgenetic research}

Much more complex, but more systematic approach by method of microgenetic research (Ristić Dedić, 2009). For systematic research of the effects for scientific, but also practical purposes the most suitable would be the method of microgenetic research. That is a methodological approach in which all the participants repeatedly, in short time interval, are exposed to the situation of learning in order to research the process of changes of knowledge, skills and understanding (Granott \& Parziale, 2002). The questions in microgenetic research regard qualitative and quantitative changes of the subject of research (language acquisition of children): how children learn, develop skills, solve problems, and find strategies), how the learning process has been carried out, which mechanism and conditions lead to a change. In this research following has been analyzed: resource (what type of experience is being acquired), rates (is the learning sudden or gradual), way (order in approaching the learning process), width (generalization of the results), and variability of the change (with different children). There are three main approaches within the data analysis method: normatively oriented approach (group averages) - oriented on the group; idiographic approach (differences among participants), oriented towards an individual and multilevel combination of changes, which examines modelling studies of individual growth (explores the individual and group together) (Ristić Dedić, 2009). The density and intensity of observations, as well as the richness of data (both qualitative and quantitative) gathered in the research, allow access to ongoing processes of learning and insight into how learners construct new knowledge and develop strategies on tasks (Ristić Dedić, 2009).

The microgenetic approach is simplified for research in which the goal is to improve the practice, and combines advantages of qualitative and quantitative approaches. The main objectives are: to determine the effects which Foreign early language learning can achieve with nursery age children (A) and to achieve insight into the uniqueness of children's experiences of each educational situation: stimulating environment of the child, the culture of the kindergartens, the work of the educators, evaluate the basic indicators of so called, in practice, "successfully implemented activity". (B) (Ristić Dedić, 2009).

The goals of quantitative part of research are connecting: specific behavior of ed- 
ucators (for. ex. activity and passivity): variation in the organization of material aspects of stimulating environment; reaction and experiences of the children (for ex. participating in the activities, duration of participating, and level of activities) (Ristić Dedić, 2009).

1. Quantitative criteria of activity efficacy are the number of children participating in particular type of activity and duration of participation of each child in the activity.

2. Quantitative aspects of the educators role are number of: verbal instructions to individual children; nonverbal ways to direct child toward activity (demonstration, offering a toy, etc.); mediation to resolve conflicts; intervention with the goal to channel unwanted behavior of the child; unwanted behavior of the child on which educator did not react)

3. Quantitative aspects of stimulating environment: number and types of the activity's centers; number and types of toys and didactic means in the activity's centers.

4. Quantitative estimations of child's involvement in the activity (estimation of the activity level in the activity).

Qualitative aspects of the research are oriented toward: interpretation of the results (learning process), insight into the new elements of educational learning situation that could not be predicted in the beginning: insight into unique child's experience (Ristić Dedić, 2009).

Levels of estimations can be on the level of longer period of time (days, weeks, month, etc.) or on the level of a day (hours, minutes). Different age group of the children (even nursery age), taking into account other demographic data (gender, education of the parents, exposure to the foreign language, for ex.). The sample in practice is mostly appropriate. Valuators can be educators, expert assistants, parents, children, other independent valuators or combined.

Microgenetic research approach has proven to be applicable for testing of different age groups (children from nursery age to elderly), and various research areas and problems - tests of attention, memory, computation, problem solving, theory of mind, conceptual understanding, scientific thinking, solving social problems, mathematical reasoning, language, motor skills, etc. (Chen and Siegler, 2000; Siegler, 2006). The data in microgenetic research are very rich and we can document the changes in the behavior of the examinee's, such as vocalizations, gestures and notes. The value of data collected in micro genetic research is that we can measure changes even in situations where there is no continuous record of behavior during the entire period of trait development that has been measured. Granott \& Parziale (2002) offer a new analysis of micro genetic research by using video footage of current behavior, direct prospective and retrospective verbal reports, records documenting the observations and conclusions of the subjects. Micro genetic data are more detailed than those obtained with other types of research. They are almost always qualitative and quantitative, and provide access to ongoing learning process, and keep track of how students construct new knowledge and develop strategies on tasks. Very detailed data that are obtained from micro genetic method allows analysis of changes between different experiments (observations) and changes between waves of research, and can be analyzed on a group and individual level.

Microgenetic research approach is applicable for analyzing qualitative and quan- 
titative aspects of change. The characteristic features are being identified, patterns and mechanisms of change that is manifested in the process and cannot be detected by conventional transversal and longitudinal designs (Granott \& Parziale, 2002). In relation to these drafts, micro genetic research provides more valid data.

Microgenetic studies allow identification of sources, rates, times, and the wide of variability of change (Siegler, 2006; Siegler \& Svetina, 2002, 2006). All these elements of change are important in understanding how it unfolds. One of the key tasks of microgenetic research is to determine the source of change which is related to the cause that leads to it (Flynn \& Siegler, 2007). The mechanisms in the basis of the change can be described at different levels (social, behavioral, cognitive and biological) and each of these levels can be further analyzed at different time units. Micro genetic research is trying to discover what changes in behavior and what can be said about the source of change. We can differentiate the rate of change whether the change is sudden or gradual (Flynn, Pine \& Lewis, 2006) and there are two different concepts: a) the time - period or amount of experience needed for a new strategy or behavior to appear for the first time in the repertoire of behavior (discovery rate) and b) the time - period or amount of experience that separates the initial use of new strategies and consistently use this strategy in the tasks of the same area (incorporation rate). In micro genetic research it is often analyzed the activity and the effect of examinees in the period of rapid learning, the tests immediately before and immediately after the discovery of new strategies. It is identified and observed sequence of strategies that examinees used or representations that create problems, and there follows a process of learning to qualitative or quantitative changes. With the qualitative changes we understand changes in the type of knowledge or ability, and with the term quantitative changes in speed and accuracy of responses (Flynn, Pine \& Lewis, 2006).

Studies show systematically that students' progress through developmental sequences of qualitatively different approaches, but also that the progress from one step to another develops in a complex manner, with jumps, delays, regression and parallel use of different approaches (Siegler, 2006).

The path of change also gives information about the types of knowledge that the examinee has before achieving full competency in a given area (Flynn \& Siegler, 2007). In micro genetic research a variability of change is considered as an important phenomena and not a mistake that should be minimized in the study (Flynn \& Siegler, 2007). To understand the mechanisms in the basis of change it is important an intra - individual variability. If we use the initial variability the prediction and the posterior outcomes are more accurate (Siegler, 2006). The question is how much a behavior of individual subjects in similar tasks within one area is variable and can similar patterns of change be observed by the various key subjects in micro genetic research (Flynn, Pine \& Lewis, 2006). Survey results indicate that there is great variability in learning, both between subjects and within the same subject who solve the problem at close intervals, even within the same measurement (Siegler, 2006) because micro genetic research is particularly focused on the individual, process data which enable the identification of irregular aspects of change linked with the path, rate and width of the change. 
Although the method of micro genetic research has many advantages, in practice it is often impossible to implement the psychological tests to monitor children's development and identify children's specific knowledge, e.g. in the field of foreign languages. Due to the frequent inability of the experts of different profiles (e.g., psychologists, educators, teachers of foreign languages) continuously evaluate independently the developmental status of the child; it is necessary that the people residing with children work with them, such as kindergarten teachers, and parents at home.

In order to make evaluation, a list of relevant competencies of children should be made, and then evaluate the status of these characteristics for each child, in relation to the orientation "norm" (age-adjusted mental and physical capabilities). Evaluating the development of children in this way, not only we can carry out prevention at the individual level but also at the level of whole group of children (e.g. children in the educational group in the kindergarten).

For practical purposes, a simple quantitative method can be frequently sufficient, which can plan the process of improving the child development based on evaluation of the status (Sindik 2001, 2008).

\section{INSTEAD OF CONCLUSION}

We gave an overview of some process influencing the children's ability to acquire language by scrutinizing theories dealing with language learning, that are explaining the ability of the child to discriminate speech sound (nativists, empiricists - behaviorists, cognitivists).

The basic approaches that dominate all theories of language learning are the process of learning and acquiring the language rules, which is a less significant factor when comparing to the innate one, while it is presumed that there are predetermined language universalities in child's predisposition or ability to learn language. An argument for the innate factor is the fact that the child has significant grammar knowledge. Children learn through three phases: learning rhythmic characteristics of the language, segmentation of the words from fluent speech, identification of the exact grammar structure. Children can differentiate languages belonging to the different rhythmic categories at the very early stage of life and later they recognize familiar words in fluent speech. The results lead to conclusion that children have the capacity of learning language statistically. It is yet to discover how they integrate all the information needed for language learning, how they choose rules which signs are better indicators to mar boundaries between words.

The key factor for successful acquiring of the language is fun, because in the learning process, if the fun element is present, the little brain (emotional brain) is activated and thus facilitates the learning. At preschool age there is a great intrinsic motivation for language learning and learning should be stress free, while $80 \%$ of learning problems are stress related. We can make a learning process successful if we make it as natural as possible, and therefore it is important to start the second language learning process at an early stage when children are intrinsically motivated and when they have the ability to acquire knowledge 
as a part of a natural process. Up to the age 12the brain is like super - sponge and during that period the foundations for thinking, language, vision, attitudes, aptitudes and other characteristics are laid down and all the fundamental architecture of the brain is finished.

When it comes to evaluate the foreign language learning process, we should consider always developmental traits, the principles of development and the principle of development holism. The simple quantitative method was developed for the purpose with the basic idea that is necessary to encourage intensively development of those mental and physical competences that are not at some point enough developed. The evaluation of the developmental status of the child can be implemented in two ways: the progress of children, in relation to the initial state for each individual (how much the child has progressed in relation to the initial evaluation in a developmental area), or may be evaluate an absolute status or condition of the specific characteristics regardless of initial state (when compared with the average of the group). The method is suitable because evaluation of the children can be done by not particularly scientifically educated teachers and thus it can be followed an overall developmental status of the child; overall psychological and physical development, development of the speech, direct cognition from the area of concrete foreign language, child's choice among the activities he/she plays, environmental conditions needed for the activities with the children, participation of the children in selected and conducted activities.

For the scientific purposes we can use the method of microgenetic research which regards the qualitative and quantitative changes of the subject of research (language acquisition of the children) and has a methodological approach in which all the participants are exposed to situation of learning in order to examine the process of development. The simplified microgenetic approach is combined with quantitative and qualitative approach in order to improve the practice, i.e. to determine what effects have foreign language learning at an early age.

With microgenetic research we can record the changes in the behavior such as vocalizations, gestures and notes and we can measure it even in non-continuous record of behavior. Although the method of micro genetic research is suitable for monitoring a great range of developmental changes it is somewhat impossible to implement the psychological tests to monitor children's development and identify children's specific knowledge in the field of foreign language. In order to make evaluation possible, a list of competencies should be made and we can evaluate the status of the characteristics of each child and it is possible to monitor progress of development at the individual and group level.

\section{BIBLIOGRAPHY}

1. Barać, J., Sindik, J. (1999). Program ranog učenja talijanskog jezika u dječjem vrtiću. Zbornik radova 1. Dana Učiteljske akademije u Zagrebu. De Zan, Ivan, ed. Zagreb: Učiteljska akademija, 251-256.

2. Bloom, B.S. (1964). Stability and Change in Human Characteristics. New York: Wiley.

3. Brumen, M. (2011). The perception of and motivation for foreign language learning 
in pre-school. Early Child Development and Care 181(6): 717-732.

4. Bruner, J.S. (1966). Studies in Cognitive Growth (Infancy): New York: Wiley.

5. Bruner, J. S. (1983). Child's Talk: Learning to Use Language: W.Washington: Norton.

6. Brewer, C., Campbell, D. (1998). Rhythms of Learning. Tucson: Zephyr.

7. Buzan, T. (1984). Use your memory. London: Guild Publishing.

8. Chen, Z. Siegler, R. (2000). III Microgenetic methods. Monographs of the Society for Research in Child Development 65(2): 12-16.

9. Chen, Zhe, Robert Siegler (2000). Across the great divide: Bridging the gap between understanding of toddlers' and older children's thinking. Monographs of the Society for Research in Child Development 65.2: (Whole No. 261).

10. Chomsky, N. (1968). Language and Mind. New York: Harcourt Brace.

11. Chomsky, N. (1980). Rules and Representations: New York: Columbia University Press.

12. Clark, H.H., Clark, E. (1977). Psychology and Language. New York: Harcourt, Brace Jovanovich.

13. Diamond, M.C. (1988). Enriching Heredity: The Impact of the Environment on the Anatomy of the Brain. LA: University of California, Free Press.

14. Doupe, A.J., Kuhl, P.K. (1999). Birdsong and human speech: Common themes and mechanisms. Annual Review of Neuroscience 22: 567-631.

15. Dryden, G., Rose, C. (1995). Fundamentals. United Kingdom: Accelerated Learning Systems.

16. Dryden, G., Vos, J. (1997). The Learning Revolution. Auckland, NZ: The Learning Web.

17. Flynn, E., Pine, K., Lewis, C. (2006). The microgenetic method: Time for change? The Psychologist 19(3): 152-155.

18. Flynn, E, Pine, K., Lewis, C. (2007). Using the microgenetic method to investigate cognitive development: An introduction. Infant and Child Development 16:1-6.

19. Flynn, E., Siegler, R. (2007). Measuring change: Current trends and future directions in microgenetic research. Infant and Child Development 16: 135-149.

20. French, R.M. (2008). A new manifesto for child development. Behavioral and Brain Sciences, Cambridge University Press 31(3): 239-240.

21. Gardner, H. (1983). Frames of Mind: The theory of multiple intelligences. New York: Basic Books.

22. Granott, N., Parziale, J. (2002). Microdevelopment: A process-oriented perspective for studying development and learning. Microdevelopment: Transition processes in development and learning, Granott Nira, Parziale Jim, eds. Cambridge: Cambridge University Press, 1-28.

23. Jensen, E. (1994). The Learning Brain. San Diego: Turning Point for Teachers.

24. Jusczyk, P.W., Aslin, R.N. (1995). Infants' detection of the sound patterns of words in fluent speech. Cognitive Psychology 29: 1-23.

25. Krashen, S. (1992). Fundamentals of Language Education. Beverly Hills: Laredo.

26. Lennenberg, E.H. (1967). Biological Foundations of Language: New York: Wiley.

27. Lozanov, G. (1978). Outlines of Suggestopedy. New York: Gordon \& Breech. 
28. MacLean, P.D. (1990). The Triune Brain in Evolution. New York: Plenum.

29. Marcos, K. (2009) The Benefits of Early Language Learning. Retrieved 15.5.2010. from: http://imsnc.org/blog/articles-helpful-resources/the-benefits-of-early-language-learning/\#more-153.

30. Marcos, K. (2009). Why, How, and When Should My Child Learn a Second Language? Retrieved 15.5.2010. from: http://www.kidsource.com/kidsource/content3/ second.language.p.k12.2.html

31. Nazzi, Thierry, Peter W. Jusczyk, Elisabeth K. Johnson (2000). Language discrimination by English learning 8-month-olds: Effects of rhythm and familiarity. Journal of Memory and Language 43: 1-19.

32. Ornstein, E.R. (1984). The Amazing Brain. New York: Houghton Mifflin Harcourt.

33. Oxford, R.L., Cohen, A.D. (1992). Language learning strategies: Crucial issues of concept and classification. Applied Language Learning 3.1-2: 1-35.

34. Piaget, J. (1967). Biology and Knowledge. Chicago: Chicago University Press.

35. Ristić Dedić, Z. (2009). Prikaz metodoloških i analitičkih pristupa u mikrorazvojnim istraživanjima. Psihologijske teme 18.1: 1-20.

36. Sapir, E. (1921). Language. An Introduction to the Study of Speech. New York: Harcourt Brace and Co.

37. Schmidt, R. (1994). Deconstructing consciousness in search of useful definitions for applied linguistics. AILA Review 11: 11-16.

38. Siegler, Robert S. (2006). Microgenetic analysis of learning. Handbook of child psychology. Kuhn, David, Robert S. Siegler, eds. New York: John Wiley \& Sons Inc., 464-510.

39. Siegler, R.S., Svetina, M. (2002). A microgenetic/ cross-sectional study of matrix completion: Comparing short-term and long-term change. Child Development 73(3): 793-809.

40. Siegler, R.S., Svetina, M. (2006). What leads children to adopt new strategies? A microgenetic/ cros-sectional study of class inclusion. Child Development 77(4): 997-1015.

41. Sindik, J. (2001). Fleksibilno postavljanje razvojnih zadaća u planiranju odgojno-obrazovnog rada. Zbornik radova - 8. Dani predškolskog odgoja - Čakovec. Edita Slunjski, ur. Čakovec: Visoka učiteljska škola u Čakovcu, 35-40.

42. Sindik, J. (2002a). Algoritamski povezane relacijske baze podataka kao osnova planiranja u edukacijskoj i kineziološkoj psihologiji te u psihologiji rada. Knjiga sažetaka 10. godišnje konferencije hrvatskih psihologa, Plitvička Jezera. Kulenović Alija, ed. Zagreb: Hrvatsko psihološko društvo, 37-38.

43. Sindik, J. (2002b). Primjena teorije izbora u "računalnom" pristupu planiranju i vrednovanju u predškolskom i školskom odgoju i obrazovanju (princip "baza podataka”). Zbornik radova 2. Hrvatskog susreta kvalitetnih škola «RI - KVAŠ 21 - Svaki učenik može uspjeti». Tonšić-Krema, Jagoda, Milivoj Vrabec, Antun Toni Štemberger, eds. Rijeka: Grad Rijeka; Medicinska škola Rijeci; Ministarstvo prosvjete i športa, 151-156.

44. Sindik, J. (2008). I okvirna psihološka procjena može doprinijeti prevenciji pojave 
posebnih potreba predškolske djece. Hrvatski časopis za javno zdravstvo, 4.14. Retrieved 15.5.2010. from: http://www.hcjz.hr/clanak.php?id=13743\&rnd

45. Skinner, B.F. (1957). Verbal Behavior. Acton, Massachusetts: Copley Publishing Group.

46. Skinner, B.F. (1989). Recent Issues in the Analysis of Behavior. Ohio: Columbus, Merrill Publishing Company.

47. Stokes, G., Whiteside, D. (1984). Basic one brain: Dyslexic learning correction and brain integration. CA, Burbank: Three In One Concepts, Inc.

48. Vygotsky, L.S. (1986) Thought and Language - Revised Edition. Baskerville: The Massachusetts Institute of Technology.

49. Vos, J. (2008). Can Preschool Children Be Taught a Second Language?, Earlychildhood News. Retrieved 15.5.2010. from: http://ww.earlychildhoodnews.com/earlychildhood/article_view.aspx?ArticleId=60

50. Whorf, B. (1956). Language, Thought and Reality. Carroll, John B. ed. Baskerville: The Massachusetts Institute of Technology.

\section{UČENJE STRANOG JEZIKA KOD PREDŠKOLSKE DJECE: METODE VREDNOVANJA U OKRUŽENJU DJEČJEG VRTIĆA}

\section{SAŽETAK}

U radu opisujemo kako djeca usvajaju jezik. Poznato je da je rana dob najprikladnija za početak učenja stranoga jezika. Djelomično je tomu razlog što dijete do određene dobi učenje stranoga jezika doživljava kao dio prirodnog procesa. Za naše smo istraživnje morali proučiti teorije učenja jezika, nativističku teoriju usvajanja prema kojoj, Chomsky tvrdi, postoji urođeni faktor, to jest jezični skup informacija, a Lenneber kasnije te teorije razvija. Također smo istražili empirijsko - bihevioralnu teoriju, čiji predstavnik Skinner zagovara da je za razvoj jezika nužno imitiranje koje dijete čini te naposlijetku kognitivna teorija koja zagovara da spoznaja prethodi razvoju jezika (Bruner, Piaget, Vygotsky, Sapir-Whorf). Pokušali smo dati pregled procesa i načina usvajanja stranog jezika, proučavali smo faze učenja jezika i veze s razvojnim stupnjevima mozga. Ustanovljeno je da je najpogodnija dob za početak procesa učenja stranog jezika predškolska dob, kad su djeca većinom intrinzično motivirana. Za evaluaciju procesa predlažemo jednostavnu kvalitativnu i kvantitativnu metodu za odgajatelje i roditelje, a za znanstveno istraživanje i dublje razumijevanje procesa usvajanja jezika i promjena koje se pritom događaju koristi se metoda mikrorazvojnog (mikrogenetskog) istraživanja.

Ključne riječi: intrinzična motivacija, kvantitativna i kvalitativna metoda, mikrorazvojno istraživanje, učenje stranog jezika 